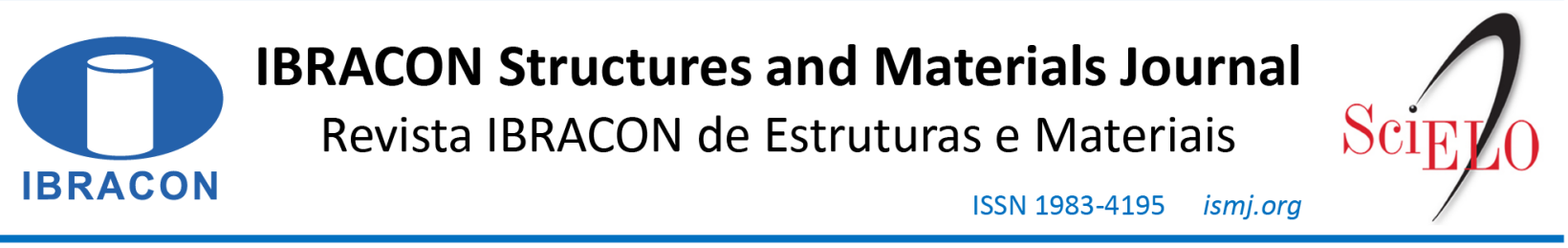

ORIGINAL ARTICLE

\title{
Evaluation of different fly ash samples on the production of alkali-activated materials
}

\section{Avaliação de diferentes amostras de cinza volante na produção de materiais álcali- ativados}

\author{
Adriano Galvão Souza Azevedo ${ }^{a}$ \\ Luis Fernando Tonholo Domingos ${ }^{\mathrm{a}}$ (D) \\ Kurt Strecker $^{\mathrm{a}}$
}

${ }^{a}$ Universidade Federal de São João del-Rei, Departamento de Engenharia Mecânica, São João del-Rei, MG, Brasil

Received 22 April 2020

Accepted 11 January 2021

\begin{abstract}
In this work, different samples of fly ash (FA-A and FA-B) classified as type F as used to produce the AAM samples. The FA-A presented a higher $\mathrm{Fe}_{2} \mathrm{O}_{3}$ content than FA-B, 6.1 to 3.8 wt. $\%$, and a slightly higher $\mathrm{SiO}_{2} / \mathrm{Al}_{2} \mathrm{O}_{3}$ ratio of 3.52 in comparison to 3.34 of $\mathrm{FA}-\mathrm{B}$. The average particle size (D50) of fly ash $\mathrm{A}$ was $19.7 \mu \mathrm{m}$ and of fly ash B $30.8 \mu \mathrm{m}$, while the specific mass of the ashes A and B were 2.38 and $2.21 \mathrm{~g} / \mathrm{cm}^{3}$, respectively. The results revealed that the mechanical strength of the AAM produced with fly ash A was higher than fly ash B, close to 80 and $44 \mathrm{MPa}$, respectively. The variation of the strength has been attributed to the different $\mathrm{SiO}_{2} / \mathrm{Al}_{2} \mathrm{O}_{3}$ ratios and different particle sizes. The mechanical strength decreased with increasing curing time, which is attributed to excess alkali in the system. Only very small differences in porosity and density have been found.
\end{abstract}

Keywords: alkali-activated materials, fly ash, alkali activation, mechanical strength.

Resumo: Neste trabalho, diferentes amostras de cinza volante (CV-A e CV-B) classificadas como tipo F foram usadas para a produção dos AAM. A amostra CV-A apresentou uma maior concentração de $\mathrm{Fe}_{2} \mathrm{O}_{3}$ $(6,1 \%)$ em comparação a amostra CV-B (3,8\%). A razão $\mathrm{SiO}_{2} / \mathrm{Al}_{2} \mathrm{O}_{3}$ foi de 3,52 e 3,34 para as amostras CVA e CV-B, respectivamente. O tamanho médio das partículas (D50) foi de 19,7 $\mu \mathrm{m}$ (CV-A) e 30,8 $\mu \mathrm{m}$ (CVB), enquanto a massa específica foram 2,38 e $2,21 \mathrm{~g} / \mathrm{cm}^{3}$, respectivamente. A resistência mecânica das amostras produzidas com a CV-A foi de $80 \mathrm{MPa}$ enquanto valores próximos de $44 \mathrm{MPa}$ foram obtidos com a CV-B. Essa variação foi relacionada com os diferentes tamanhos médios das partículas da cinza. A diminuição da resistência foi relacionada com o álcali em excesso no sistema. Pequenas variações nos valores de porosidade e densidade foram observadas nas amostras produzidas.

Palavras-chave: materiais álcali-ativados, cinza volante, álcali-ativação, resistência mecânica.

How to cite: A. G. S. Azevedo, L. F. T. Domingos, and K. Strecker, "Evaluation of different fly ash samples on the production of alkali-activated materials," Rev. IBRACON Estrut. Mater., vol. 14, no. 6, e14601, 2021, https://doi.org/10.1590/S1983-41952021000600001

\section{INTRODUCTION}

Ordinary Portland cement (OPC) is the most used binding material in the construction industry worldwide. However, the production of cement releases large quantities of $\mathrm{CO}_{2}$, the main greenhouse gas, which may contribute to drastic climate changes [1], [2]. According to Pedroso (2008), it is predicted that in 2030, maintaining the annual growth rate of cement production of 2008, the cement production industry will be responsible for the emission of 2820 million tons of carbon dioxide [3]. Therefore, because of the possible environmental problems, the search for new types of binders with similar properties to OPC is necessary. These alternative binding materials must be able of replacing 
traditional cement, ensuring high mechanical strength, chemical inertia, acquiring resistance in short curing periods, resistance to acid, and sulfate attacks, besides presenting low cost [4]-[6].

A new class of binders, which is also known as inorganic polymers or geopolymers, is obtained by the polycondensation or inorganic polymerization of aluminosilicate minerals in a highly alkaline environment. The term geopolymer was first described by Glukhovsky in 1959 and widely spread in the 1970s by Joseph Davidovits [7]. The nomenclature to name geopolymers is based on the term polysialate, an abbreviation for silico-oxo-aluminate, of composition $\mathrm{M}_{\mathrm{n}}\left[-\left(\mathrm{Si}-\mathrm{O}_{2}\right)_{\mathrm{z}}-\mathrm{Al}-\mathrm{O}\right]_{\mathrm{n}} \cdot \mathrm{wH}_{2} \mathrm{O}$ [8], wherein $\mathrm{M}$ is a cation such as potassium, sodium, or calcium, $\mathrm{n}$ is the degree of polycondensation, $\mathrm{z}$ is 1,2 , or 3 , indicating the $\mathrm{Si} / \mathrm{Al}$ ratio on the basic silico-aluminate unit of the polysialate [6], and $w$ corresponds to the degree of hydration. The variation of " $z$ " automatically causes a variation in the $\mathrm{SiO}_{2} / \mathrm{Al}_{2} \mathrm{O}_{3}$ ratio, which allows the formation of different types of geopolymers, such as poly(sialate) which are based on the sialate unit [-Si-Al-Si-O], with a $\mathrm{Si} / \mathrm{Al}$ ratio of $1: 1$, poly(sialate-siloxy) that have the sialate-siloxy [- $\mathrm{Si}-\mathrm{O}-\mathrm{Al}-\mathrm{O}-\mathrm{Si}-\mathrm{O}-]$ as the basic unit and a $\mathrm{Si} / \mathrm{Al}$ ratio equal to $2: 1$ and poly(sialate-disiloxy) with the sialate disiloxy [Si-O-Al-O-Si-O-Si-O-] as the basic unit and a Si/Al ratio of 3:1. The production of the alkali-activated materials is also known to form a short-range atomic array, an aluminosilicate gel which may be referred to as an N-A-S-H type gel (with $\mathrm{N}=\mathrm{Na}_{2} \mathrm{O}, \mathrm{A}=\mathrm{Al}_{2} \mathrm{O}_{3}, \mathrm{~S}=\mathrm{SiO}_{2}, \mathrm{H}=\mathrm{H}_{2} \mathrm{O}$ ). This general formula for the product of the geopolymerization shows that even after polycondensation reactions, water molecules remain in the system, promoting gel stability, and favoring the obtention of high mechanical strength materials with denser structures [9]-[12].

The geopolymer production process may become complex due to large variations in the chemical and mineralogical composition of the starting materials, which may alter the characteristics of the final product [12], [13]. Andini et al. [14] conducted a study using various types of fly ashes with different $\mathrm{SiO}_{2}$ to $\mathrm{Al}_{2} \mathrm{O}_{3}$ ratios, thus forming different types of geopolymeric structures, such as poly(sialate-siloxy) and poly(sialate-disiloxy). They used calcium hydroxide $(\mathrm{NaOH})$ and potassium hydroxide $(\mathrm{KOH})$ as alkaline activators, and for the thermal curing, the materials were submitted to different temperatures and times of exposure. It was concluded that the geopolymer materials obtained from fly ash with a $\mathrm{SiO}_{2} / \mathrm{Al}_{2} \mathrm{O}_{3}$ ratio equal to 3 resulted in materials of higher strength, lower porosity, and higher apparent density. However, the authors emphasized that the most satisfactory results were obtained when using $\mathrm{KOH}$ as an alkaline activator and curing temperature of 25 and $80^{\circ} \mathrm{C}$, but without stating the reasons for the improved performance [14]. Similar work was done by van Jaarsveld et al. [15] and they concluded that the origin of the industrial byproducts plays a fundamental role in determining the final properties of the geopolymer matrix, which may be associated with the origin of the mineral coal used and the burning process used in the thermoelectric plant.

This work presents the production of geopolymer materials using fly ash from the same thermoelectric complex obtained in different years, 2013 and 2020. This type of investigation is important to demonstrate how different fly ash samples can promote different properties for the AAM produced under the same conditions. In the work of Jahromy et al. [16], the authors demonstrated how six fly ash samples obtained in different ways have high changes in the final properties. The study of the different mineralogical characteristics of the starting material is of great interest to ascertain the modification of the physical and mechanical properties of the geopolymer matrix, as well as to give an ecologically more attractive application.

\section{JUSTIFICATION}

Correlate the chemical composition of the different fly ash samples with the mechanical and physical properties of the hardened alkali-activated materials after different curing times.

\section{MATERIALS AND EXPERIMENTAL PROGRAM}

\subsection{Materials}

\subsubsection{Fly Ash (FA)}

Two samples of fly ash from the Jorge Lacerda/SC thermoelectric complex, commercialized by Pozo-Fly industry, Lima ${ }^{\circledR}$ ash trade, were used to produce the pastes. The ashes were benefited by separation of coarse residues and ball milling. The fly ash A (FA-A) originated from the burning of coal in the thermoelectric plant in the years 2013 and 2014, while fly ash B (FA-B) was obtained in the period between 2019 and 2020. The intent of using fly ash from the same plant is to establish a relationship between the chemical composition of the ashes and the mechanical, physical, 
and chemical properties of the slurries produced by alkaline activation and how ashes from the same thermal plant can promote the obtainment of materials with different properties

\subsubsection{Sodium hydroxide $(\mathrm{NaOH})$}

The alkaline solutions were prepared using sodium hydroxide pellets provided by Sulfal Química LTDA, type P.A, with a purity of $98 \%$.

\subsection{Experimental program}

The activating solutions (alkaline solutions) were prepared by dissolving the $\mathrm{NaOH}$ in water to obtain a final concentration of 16 mol.L $\mathrm{L}^{-1}$, equivalent to about $17 \mathrm{wt} .-\%$ of $\mathrm{Na}_{2} \mathrm{O}$. Due to the exothermic nature of the $\mathrm{NaOH}$ dissolution, the solutions prepared were allowed to cool down to room temperature for at least $24 \mathrm{~h}$ before their use.

The geopolymer mixtures were produced by mixing the fly ashes with the $16 \mathrm{~mol} . \mathrm{L}^{-1} \mathrm{NaOH}$ solution at room temperature in a mechanical mixer for 5 min with a maximum capacity of 5 liters. The ratio of fly ash to the activator solution was maintained constant close to 0.5 for both mixtures. The pastes prepared were then filled into plastic molds of $50 \mathrm{~mm}$ diameter and $25 \mathrm{~mm}$ height and vibrated for 60 seconds on a vibrating table to ensure accommodation within the molds. The molds were sealed using PVC film to prevent water loss by evaporation. After 24 hours, the plastic film was removed, and the samples were cured at $90^{\circ} \mathrm{C}$ for $24 \mathrm{~h}$. The hardened specimens were removed from the molds and further cured at room temperature for 1, 7, and 28 days [16]. The samples produced with fly ash A (FA-A) and B (FA-B) are denominated GP-A and GP-B, respectively, further adding the time of curing. For example, sample GP- A- 7 corresponds to a sample prepared with fly ash of type A (FA-A) cured for 7 days.

\subsection{Characterization of precursor materials and the geopolymer pastes}

The FA samples were characterized using a Shimadzu Energy Dispersive X-Ray Fluorescence, model EDX 8000 to determine the chemical composition. The particle size distribution of the fly ashes was measured by laser diffraction analysis, Malvern Mastersizer $2000(0.02-2000 \mu \mathrm{m})$, and the specific mass of the fly ashes was obtained with a Helium pycnometer, Micromeritics, model AccuPyc 1340 [17]. The morphology of the FA and the geopolymer samples were analyzed using scanning electron microscopy, Hitachi, model TM 300 with coupled EDS, Bruker, model X-Flash. The physical properties of the geopolymers were determined following the recommendations of the British standard BS EN ISO 10545-3 [18]. Infrared spectroscopy was carried out using a PerkinElmer Spectrometer, model Spectrum 1000. The analysis was done by mixing inorganic binder samples in powder form with $\mathrm{KBr}$ (1:300), compacting pellets, and analyzing the sample in the range of 400 to $4000 \mathrm{~cm}-1$ with a resolution of $4 \mathrm{~cm}^{-1}$.

A total of 10 specimens for each preparation condition were used for the measurement of the compressive strength and physical analysis. The samples were characterized by uniaxial compression as described in standard NBR - 5739 [19], using a universal testing machine, Shimadzu model AG - X Plus, under a crosshead speed of $2 \mathrm{~mm} / \mathrm{min}$.

Present the physical, chemical and mechanical characterization of the materials used in the experimental program. Describe the laboratory investigations and procedures.

\section{RESULTS AND DISCUSSIONS}

\subsection{Characterization of Fly Ash Samples}

The particle size distribution of fly ash samples A and B are presented in Figure 1. The two ashes used in the process of geopolymer production exhibit different particle size distributions. The samples presented the particle size D10, D50, and D90, listed in Table 1, which correspond to the sizes of 10, 50, and 90\% of the accumulated mass of the fly ash powders, respectively. The specific mass of the two FA samples is also presented in Table 1. 


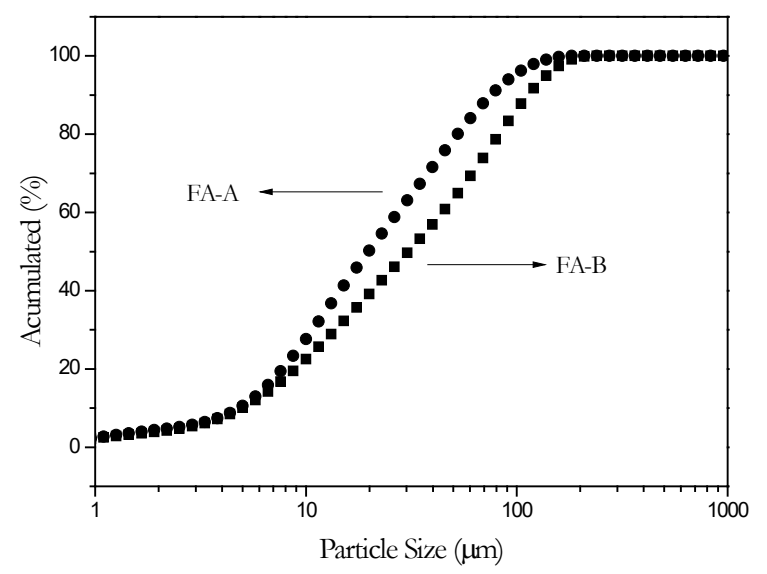

Figure 1. Particle size distribution of the fly ash samples FA-A and FA-B.

Table 1. D10, D50 and D90 equivalent sizes and specific mass of fly ash samples.

\begin{tabular}{|c|c|c|c|c|}
\hline \multirow{2}{*}{ Sample } & D10 & D50 & D90 & \multirow{2}{*}{ Specific mass $\left(\mathrm{g} / \mathrm{cm}^{3}\right)$} \\
\hline & $(\mu \mathrm{m})$ & $(\mu \mathrm{m})$ & $(\mu \mathrm{m})$ & \\
\hline FA-A & 4.81 & 19.70 & 75.44 & 2.38 \\
\hline FA-B & 4.97 & 30.82 & 112.87 & 2.21 \\
\hline
\end{tabular}

The chemical compositions of fly ash samples $\mathrm{A}$ and $\mathrm{B}$ are shown in Table 2. It is possible to see that the ashes consist basically of $\mathrm{SiO}_{2}, \mathrm{Al}_{2} \mathrm{O}_{3}$, and $\mathrm{Fe}_{2} \mathrm{O}_{3}$. It was observed similar composition of the $\mathrm{FA}$ in the work of Azevedo et al. [17], that the authors studied the production of fly ash-based alkali-activated materials with simple and compound solutions of $\mathrm{NaOH}$ and $\mathrm{Na}_{2} \mathrm{SiO}_{3}$. Other chemical elements are also present in lower concentrations. According to the chemical composition, both fly ashes can be classified as type F, in which the sum of the $\mathrm{SiO}_{2}, \mathrm{Al}_{2} \mathrm{O}_{3}$, and $\mathrm{Fe}_{2} \mathrm{O}_{3}$ concentrations is higher than $70 \%$ and the $\mathrm{CaO}$ concentration lower than $10 \%$, according to ASTM C 618 [20]. The high concentration of Si and Al in the samples is mainly due to the mineral origin of these ashes which originate from the burning of coal. The organic matter present in the coal is decomposed at high temperatures while the inorganic material is entrained and collected by the electrostatic precipitators installed in the chimneys. This material retained is the fly ash, presenting elevated amounts of amorphous aluminosilicates, which turns the ashes susceptible to an alkaline attack to produce the AAM. The molar ratio $\mathrm{SiO}_{2} / \mathrm{Al}_{2} \mathrm{O}_{3}$ is higher for fly ash $\mathrm{A}$, 3.52 , compared to 3.34 of fly ash $\mathrm{B}$. A high $\mathrm{SiO}_{2} / \mathrm{Al}_{2} \mathrm{O}_{3}$ molar ratio is desirable to promote more $\mathrm{Si}$ released during the dissolution process of the raw material and consequently a larger amount of N-A-S-H gel formed (AAM) [17].

Table 2. The chemical composition of fly ash samples used in the production of the alkali-activated materials.

\begin{tabular}{cccccc}
\hline Sample & $\mathbf{S i O}_{2}$ (wt.-\%) & $\mathbf{A l}_{2} \mathbf{O}_{3}$ (wt.-\%) & $\mathbf{F e}_{2} \mathbf{O}_{3}$ (wt.-\%) & Other Oxides* ${ }_{(\text {wt.-\%) }}$ & $\mathbf{S i O}_{2} / \mathbf{A l}_{2} \mathbf{O}_{3}$ *** \\
\hline FA-A & 61.025 & 29.406 & 6.155 & 3.414 & 3.52 \\
\hline FA-B & 61.546 & 31.234 & 3.884 & 3.336 & 3.34 \\
\hline
\end{tabular}

$*\left(\mathrm{ZnO}, \mathrm{CaO}, \mathrm{Na}_{2} \mathrm{O}, \mathrm{K}_{2} \mathrm{O}, \mathrm{MnO}, \mathrm{Cr}_{2} \mathrm{O}_{3}, \mathrm{SrO}, \mathrm{CuO}, \mathrm{Rb}_{2} \mathrm{O}, \mathrm{Y}_{2} \mathrm{O}_{3}, \mathrm{PbO}, \mathrm{Ga}_{2} \mathrm{O}_{3}, \mathrm{GeO}_{2}, \mathrm{NiO}\right.$ e $\left.\mathrm{NbO}\right) * *$ Molar ratio.

Figure 2 shows SEM images of particles of FA-A and FA-B used in the production of the alkali-activated materials. Both fly ash powders present spherical particles, with sizes ranging from approximately 5 to $200 \mu \mathrm{m}$, consistent with the results of particle size analysis by laser diffraction analysis, see Figure 1 and Table 1. 


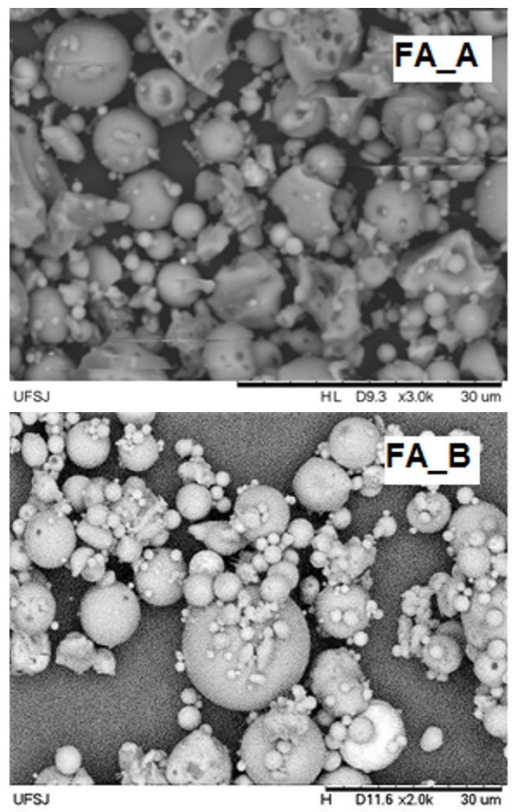

Figure 2. Scanning electron microscopy of FA-A, and FA-B.

The particles of FA-A are less homogeneous than the particles of FA-B and some non-spherical fragments are also observed, which may be produced during the milling process of the residue before its distribution by the company. The chemical composition of the fly ash samples and the EDS spectra related to the $\mathrm{Si}$, Al, and Fe elements are shown in Table 3 and Figure 3. The chemical composition is similar to that found in the FRX results showed in Table 2.

Table 3. EDS analysis of FA-A and FA-B.

\begin{tabular}{ccc}
\hline & Element & [at. \%] \\
\hline \multirow{2}{*}{ FA-A } & $\mathrm{Si}$ & 72.09 \\
\cline { 2 - 3 } & $\mathrm{Al}$ & 25.50 \\
\cline { 2 - 3 } & $\mathrm{Fe}$ & 2.41 \\
\hline \multirow{2}{*}{ FA-B } & $\mathrm{Si}$ & 66.56 \\
& $\mathrm{Al}$ & 29.62 \\
\cline { 2 - 3 } & $\mathrm{Fe}$ & 3.82 \\
\hline
\end{tabular}
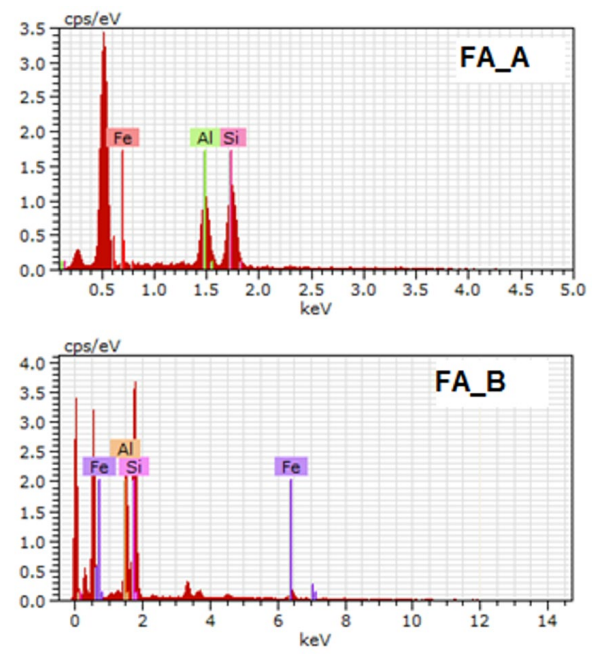

Figure 3. EDS spectra of the elements present on the surface of fly ash particles of FA-A and FA-B. 


\subsection{Characterization of the alkali-activated materials}

\subsubsection{Water absorption, porosity, and density}

The results of water absorption, apparent porosity, and density of the AAM produced with fly ash samples A and B are shown in Table 4. It is possible to observe that the geopolymer matrices produced with FA-A presented higher water absorption than the materials synthesized with FA-B. The apparent porosity of the matrices GP-A and GP-B were close to $20 \%$; the highest porosity value $(21.1 \%)$ was observed for the sample GP-A-1, produced with FA-A after 1 day of curing, and the lowest (19.2\%) was found when the sample was synthesized with FA-B after 7 days of curing. The density of the hardened matrices varied between 1.6 and $1.8 \mathrm{~g} / \mathrm{cm}^{3}$, demonstrating that the new structure formed after the geopolymerisation and formation of the N-A-S-H gel presents a lower density than that observed for the original fly ash, see Table 4.

Table 4. Water absorption, apparent porosity and density of the alkali-activated materials produced with FA-A and FA-B after 1, 7 and 28 days of cure.

\begin{tabular}{cccc}
\hline Sample & Water absorption (\%) & Apparent porosity (\%) & ${\text { Density }\left(\mathbf{g} / \mathbf{c m}^{\mathbf{3}}\right)}$ \\
\hline GP-A - 1 & $13.2 \pm 0.5$ & $21.1 \pm 0.9$ & $1.6 \pm 0.1$ \\
\hline GP-A - 7 & $13.5 \pm 0.5$ & $20.7 \pm 0.7$ & $1.6 \pm 0.1$ \\
\hline GP-A - 28 & $12.4 \pm 0.1$ & $20.0 \pm 0.2$ & $1.6 \pm 0.2$ \\
\hline GP-B - 1 & $12.3 \pm 0.4$ & $20.6 \pm 0.5$ & $1.7 \pm 0.1$ \\
\hline GP-B - 7 & $6.4 \pm 0.5$ & $19.2 \pm 0.5$ & $1.8 \pm 0.1$ \\
\hline GP-B - 28 & $9.7 \pm 0.3$ & $20.2 \pm 1.5$ & $1.7 \pm 0.2$ \\
\hline
\end{tabular}

\subsubsection{Microstructural analysis}

The scanning electron microscopy images of the AAM samples produced with fly ashes A and B are presented in Figure 4. It is possible to observe that the samples synthesized with FA-A presented a more homogeneous surface without the presence of unreacted spheres. The absence of unreacted FA particles can be related to the greater effectiveness of the dissolution of the particles found in this fly ash. The increase in the dissolution rate is linked to the improvement in the mechanical strength of the samples, as discussed below. With an increased dissolution of the fly ash particles, higher amounts of $\mathrm{Si}$ and Al-rich species will be released into the system, which, after the polycondensation reactions, results in a high amount of the N-A-S-H gel, which is responsible for the increase in compressive strength [21]-[24].

In the samples produced with FA-B, it is possible still to observe some spherical particles after contact with the alkaline solution. The presence of these particles may be associated with the lower dissolution of this material in the alkaline environment promoted by the $16 \mathrm{~mol}$. $\mathrm{L}^{-1} \mathrm{NaOH}$ solution. The presence of the spherical particle after the contact the fly ash with the activator solution was observed in the work of Morsy et al. [25], that the authors founded fly ash particles embedded in a continuous matrix rich in $\mathrm{Si}, \mathrm{Al}$, and $\mathrm{Na}$ (N-A-S-H gel). The spheres present in the system are embedded in the aluminosilicate gel formed. The surface of these particles is intact, and it is possible to observe that their interior was dissolved by the alkaline activator. This fact, according to Provis et al. [5], is due to the difference in the cooling rate of these particles during the burning of mineral coal in the furnaces. According to the authors, the ash particles may have different chemical compositions even if they are next to each other. This variation is associated with the composition of the coal used in the electrical power plant and the cooling rate of the melting mass after the burning process of the coal. The rate of cooling can promote the formation of different ordered structures (long-range and short-range atomic ordering) that have different dissolution rates in the alkaline environment. 

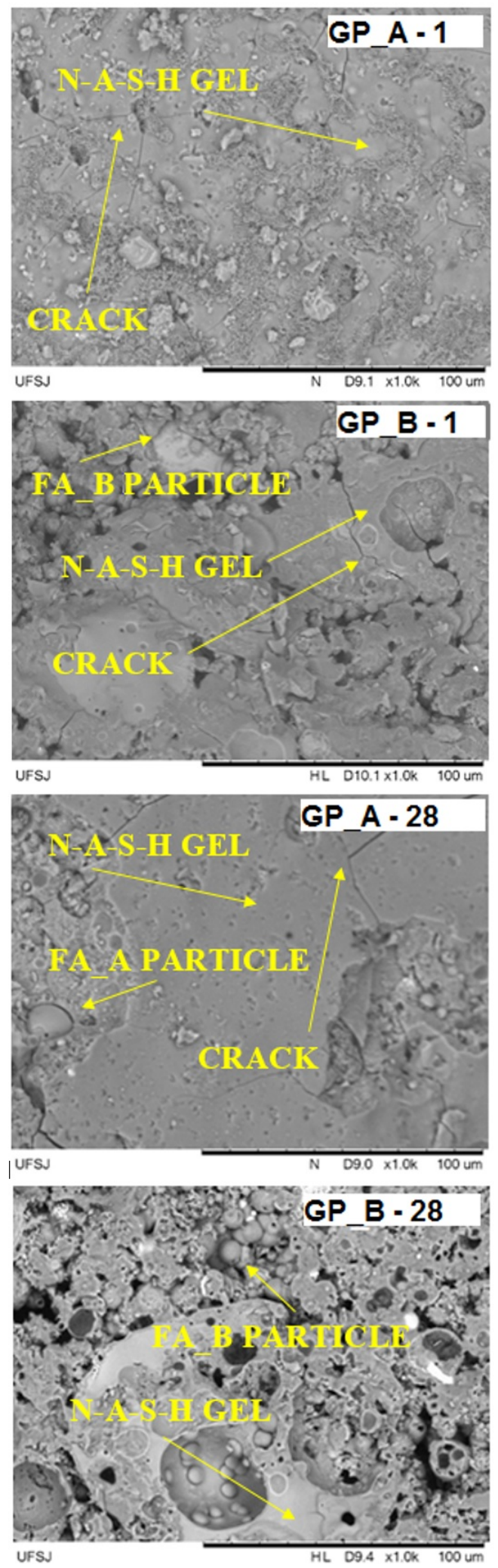

Figure 4. SEM images of the alkali-activated samples produced with the different fly ash samples after 1 (GP-A - 1 and GP-B - 1), and 28 days (GP-A - 28 and GP-B - 28), respectively. 

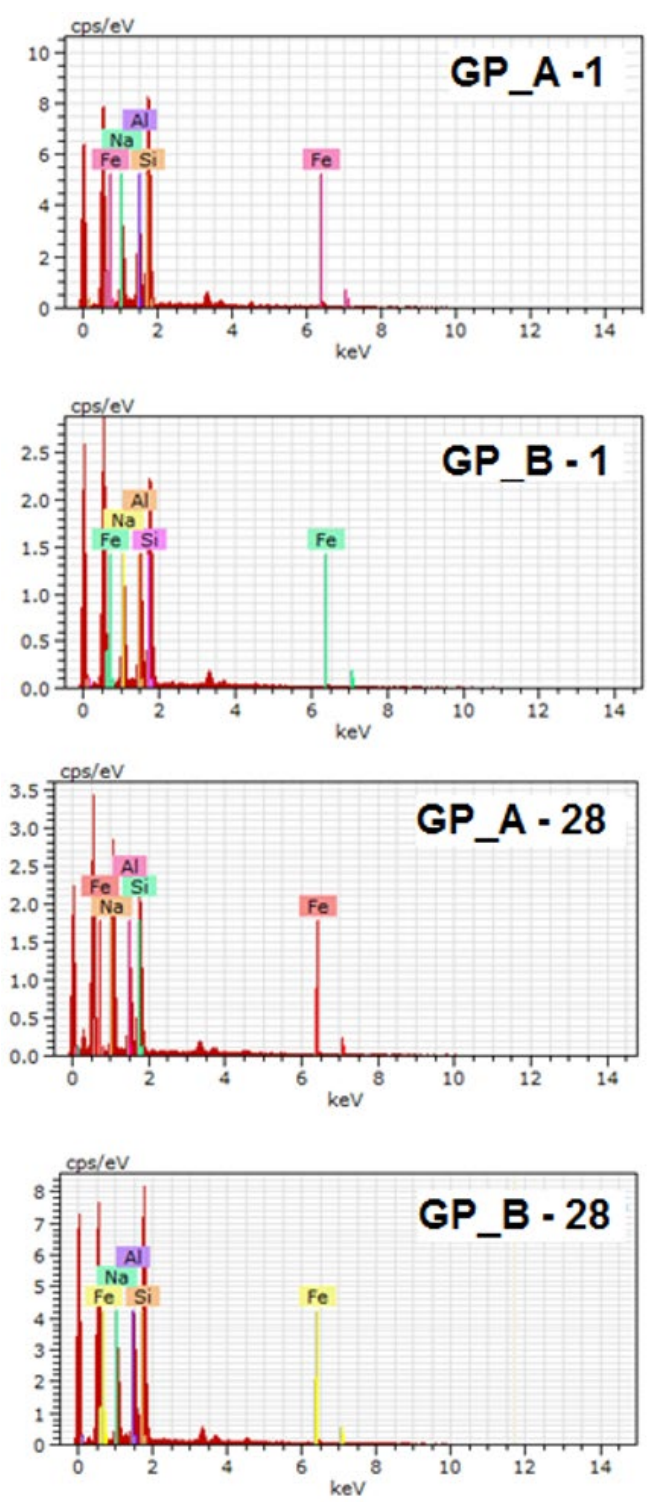

Figure 5. Spectra of the elements present on the surface of the alkali-activated samples produced with the different fly ash samples after 1 (GP-A - 1 and GP-B - 1), and 28 days (GP-A - 28 and GP-B - 28), respectively.

The use of FA samples with different chemical compositions may have favored the appearance of some particles with different atomic compositions and arrangements. This can modify the rate of dissolution, the geopolymerization reaction and, consequently, the final properties of the hardened material. After 28 days of curing, the morphology of the samples produced with both fly ashes is presented in Figure 4. The spectra of the surface elements and the chemical composition are shown in Figures 5 and Table 5, respectively. It is possible to observe a more homogeneous surface for the sample produced with FA-A, after curing for 28 days. The presence of some cracks may be associated with the polycondensation reactions that occur during the geopolymerization, characterized by the release of water molecules. The presence of a small number of unreacted FA-A particles on the surface of the sample corroborates the results observed in the samples after $24 \mathrm{~h}$ of curing, showing that the dissolution rate was higher for the geopolymers produced with this fly ash.

In the samples produced with FA-B, some spheres of the original fly ash powder particles were observed on the surface even after curing for 28 days. This observation may be associated with a lower amount of N-A-S-H gel formed which is the main responsible for the decrease of the mechanical strength of the specimens when compared to samples produced with FA-A.

The analysis of different points on the surface of the samples after the different curing days demonstrates that a Si-Al-Na system was present in the hardened material. As shown in Table 5, the presence of Fe may be associated with unreacted fly ash 
particles that remain embedded in the aluminum silicate gel. It is known that the presence of fly ash in contact with the highly alkaline environment produced by the solution promotes the dissolution of species and subsequent reorganization (geopolymer reaction). The modification of the $\mathrm{Si} / \mathrm{Al}$ ratio is associated with changes in the structure of the new material produced after the geopolymerization reactions. EDS analysis showed that the $\mathrm{Si} / \mathrm{Al}$ ratios present on the surfaces of the materials produced with fly ash A and B are close to 2.02 and 2.47, respectively. Considering the Si/Al ratio, it is concluded that the geopolymers formed (after the geopolymerization reactions) by FA-A have the structure of the poly(sialate-siloxy), $\mathrm{Si} / \mathrm{Al}=2$, and the matrices produced with $\mathrm{FA}-\mathrm{B}$, a variation between poly(sialate-siloxy), $\mathrm{Si} / \mathrm{Al}=2$ and poly(sialate-disiloxy), $\mathrm{Si} / \mathrm{Al}=3$, respectively [21] . However, the EDS analysis shows that the amount of $\mathrm{Na}$ (from the $\mathrm{NaOH}$ solution) has its concentration increased and varies when different fly ash samples were used. During the synthesis of the geopolymers, the replacement of $\mathrm{SiO}_{4}$ species by $\mathrm{AlO}_{4}$ favors the appearance of a negative charge due to the coordination IV in which the $\mathrm{Al}^{3+}$ ion is found. The electroneutrality of the polymer network is obtained by the approximation of $\mathrm{Na}^{+}$ions to the $\mathrm{Al}$ present in $\mathrm{AlO}_{4}^{-}$. Thus, a $\mathrm{Na} / \mathrm{Al}$ ratio close to 1 corresponds to a structure in which the amount of $\mathrm{Na}$ and $\mathrm{Al}$ atoms are in the ideal proportion to obtain a stable structure after the hardening process of the pastes (electrically stable).

The $\mathrm{Na} / \mathrm{Al}$ ratio of the matrices after 24 hours of curing is close to 1.0 for both samples produced with FA-A and FA-B. However, after 28 days of curing, samples produced with FA-A showed an increased Na/Al surface concentration for 2.07, as showed in Table 5. Such excess sodium on the surface of the matrices may be associated with the decrease of the mechanical strength of the specimens of GP-A after 28 days of curing. Excess $\mathrm{Na}^{+}$ion in the matrices can cause deterioration of the formed polymer structure, which is reflected by the decrease of the maximum strength of the matrices. On the other hand, FA-B produced a geopolymeric matrix with a $\mathrm{Na} / \mathrm{Al}$ ratio of 0.99 after 28 days of curing, demonstrates that this matrix produced with a $\mathrm{Na}$ and $\mathrm{Al}$ concentration close to the ideal and without $\mathrm{Na}^{+}$in excess maintained good mechanical strength exhibiting a strength decrease of only 3.8\% after 28 days of cure. Otherwise, the matrices produced with FA-A showed a decrease of strength close to $19 \%$ after the same curing period. These results show that the increase of the $\mathrm{Na} / \mathrm{Al}$ ratio in the system produced with FA-A resulted in a reduction of the compressive strength near to 5 times higher when compared to the materials produced by the alkaline activation of FA-B. This increase in the amount of $\mathrm{Na}$ on the surface and the consequent decrease in the mechanical strength of the material can be observed by spectroscopy analysis that shows the formation of new sodium-rich phases on the material surface after 28 days of curing.

Table 5. Chemical composition of the alkali-activated materials produced with the different fly ash samples.

\begin{tabular}{|c|c|c|c|c|}
\hline Sample - Curing time (days) & Element & [at.- \%] & $\mathrm{Si} / \mathrm{Al}$ ratio & $\mathrm{Na} / \mathrm{Al}$ ratio \\
\hline \multirow{4}{*}{ FA-A -1} & $\mathrm{Si}$ & $49.77 \pm 0.1$ & \multirow{4}{*}{$2.02 \pm 0.2$} & \multirow{4}{*}{$0.99 \pm 0.3$} \\
\hline & $\mathrm{Al}$ & $24.61 \pm 0.2$ & & \\
\hline & $\mathrm{Na}$ & $24.30 \pm 0.2$ & & \\
\hline & $\mathrm{Fe}$ & $1.32 \pm 0.4$ & & \\
\hline \multirow{4}{*}{ FA-A -28} & $\mathrm{Si}$ & $38.97 \pm 0.2$ & \multirow{4}{*}{$2.01 \pm 0.3$} & \multirow{4}{*}{$2.07 \pm 0.4$} \\
\hline & $\mathrm{Al}$ & $19.37 \pm 0.4$ & & \\
\hline & $\mathrm{Na}$ & $40.24 \pm 0.5$ & & \\
\hline & $\mathrm{Fe}$ & $1.43 \pm 0.4$ & & \\
\hline \multirow{4}{*}{ FA-B - 1} & $\mathrm{Si}$ & $52.76 \pm 0.1$ & \multirow{4}{*}{$2.47 \pm 0.3$} & \multirow{4}{*}{$1.05 \pm 0.1$} \\
\hline & $\mathrm{Al}$ & $21.39 \pm 0.5$ & & \\
\hline & $\mathrm{Na}$ & $22.42 \pm 0.2$ & & \\
\hline & $\mathrm{Fe}$ & $3.43 \pm 0.1$ & & \\
\hline \multirow{4}{*}{ FA-B -28} & $\mathrm{Si}$ & $55.57 \pm 0.1$ & \multirow{4}{*}{$2.62 \pm 0.2$} & \multirow{4}{*}{$0.99 \pm 0.2$} \\
\hline & $\mathrm{Al}$ & $21.18 \pm 0.1$ & & \\
\hline & $\mathrm{Na}$ & $21.17 \pm 0.5$ & & \\
\hline & $\mathrm{Fe}$ & $2.08 \pm 0.4$ & & \\
\hline
\end{tabular}

\subsubsection{Infrared Spectroscopy (FTIR)}

Figure 6 presents the infrared spectra of the original FA samples and the AAM produced with alkaline activation after 28 days of curing. The absorption bands of the fly ash and AAM at 3667 and $1641 \mathrm{~cm}^{-1}$ are due to the stretching and deformation of $\mathrm{H}-\mathrm{O}-\mathrm{H}$ and $\mathrm{O}-\mathrm{H}$ groups, respectively. These bands are related to weakly bound water molecules, adsorbed on the surface or trapped in the cavities of the inorganic binder [26]. Bands at 1090 and $458 \mathrm{~cm}^{-1}$ are associated with the stretching and bending of Si-O or Al-O bands, respectively [27]. 


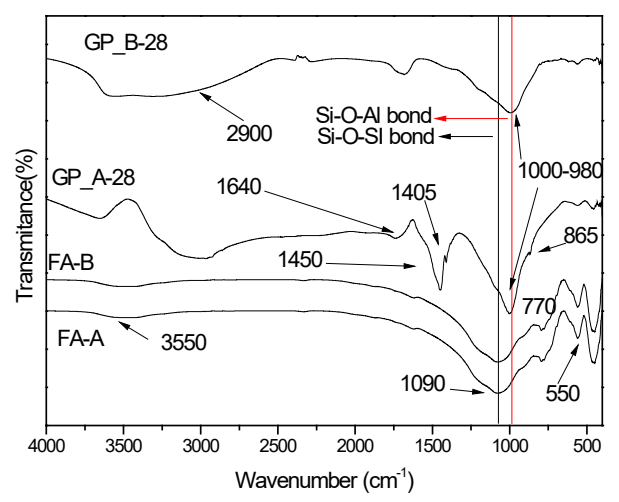

Figure 6. FTIR spectra of hardened samples produced with different fly ash samples after 28 days.

The band observed close to $1090 \mathrm{~cm}^{-1}$ is shifted to wavenumbers close to $1000-990 \mathrm{~cm}^{-1}$. This shift is related to the formation of $\mathrm{N}-\mathrm{A}-\mathrm{S}-\mathrm{H}$ gel after contact with $\mathrm{NaOH}$ solution and presents the formation of a three-dimensional structure with cementing properties [20]. Changing the Si-O absorption band to shorter wavelengths indicates the incorporation of $\mathrm{Al}^{3+}$ into $\mathrm{Si}^{4+}$ sites. This shift was associated with the geopolymerization process and is titled as the digital inorganic polymer production process (AAM production). This is responsible for the aluminum IV-coordination formation and the necessity of metals cations to promote the electrical balance of the system, as previously mentioned [28]. The carbonation products can be associated to the band close to 1445 and $1405 \mathrm{~cm}^{-1}$, and represent, according to Temuujin, et. al. (2014), to the sodium carbonate $\left(\mathrm{Na}_{2} \mathrm{CO}_{3}\right)$ formation [29], as represented by Equation 1. The excess sodium present in the system after the high alkaline solution mixture can reach the surface through diffusion processes and reacting with atmospheric $\mathrm{CO}_{2}$. The presence of this absorption band can be related to the excess of $\mathrm{Na}^{+}$ions previously mentioned as responsible for the decrease in the mechanical resistance of the hardened material after 28 days [30], [31].

$\mathrm{Na}_{2} \mathrm{O}+\mathrm{CO}_{2} \rightarrow \mathrm{Na}_{2} \mathrm{CO}_{3}$

\subsubsection{Compressive strength and Young's modulus}

The mechanical strength and Young's modulus of the AAM specimens after different curing times are presented in Table 6 and Figures 7 and 8. It is possible to observe that the different fly ash samples produced materials with different mechanical strengths. The mechanical strength value close to $88 \mathrm{MPa}$ was measured for samples fabricated with FA-A after 24 hours of curing, while samples fabricated with FA-B exhibited a strength of only $44 \mathrm{MPa}$, representing a difference of approximately $50 \%$.

Table 6. Compressive strength and elastic modulus of fly ash-based alkali-activated materials after 1, 7 and 28 days of curing.

\begin{tabular}{ccc}
\hline Sample & Compressive strength (MPa) & Elastic modulus (GPa) \\
\hline GP-A - 1 & $88.5 \pm 1.1$ & $9.0 \pm 0.6$ \\
\hline GP-A - 7 & $82.3 \pm 1.1$ & $8.4 \pm 0.5$ \\
\hline GP-A - 28 & $71.1 \pm 2.1$ & $6.9 \pm 0.2$ \\
\hline GP-B - 1 & $44.2 \pm 4.5$ & $4.6 \pm 0.3$ \\
\hline GP-B - 7 & $32.5 \pm 5.0$ & $3.6 \pm 0.5$ \\
\hline GP-B - 28 & $42.5 \pm 1.7$ & $4.2 \pm 0.7$ \\
\hline
\end{tabular}

The same tendency has been observed for the elastic modulus of the alkali-activated samples. Samples produced with FA-A presented values close to $9.0 \mathrm{GPa}$, while samples produced using FA-B achieved only $4.6 \mathrm{GPa}$ after 1 day of cure. An increase in curing time promoted changes in the values of the compressive strength and, consequently, in the elastic modulus of the samples. The increase of the ratio $\mathrm{Si} / \mathrm{Al}$ in the hardened matrices is related to produce the alkali-activated material with higher mechanical strength. This can be associated with the formation of the 
geopolymeric framework with more $\mathrm{Al}$ atoms presents in the of the silicon atoms [20]. When the curing time of the samples increased, decreasing strengths were observed, which is attributed to an excess of $\mathrm{Na}^{+}$and $\mathrm{OH}^{-}$ions from the $\mathrm{NaOH}$ solutions that promote the deterioration of the gel N-A-S-H gel of the structure $\left(\mathrm{N}=\mathrm{Na}_{2} \mathrm{O}, \mathrm{A}=\mathrm{Al}_{2} \mathrm{O}_{3}, \mathrm{~S}=\mathrm{SiO}_{2}\right.$, $\mathrm{H}=\mathrm{H}_{2} \mathrm{O}$ ), responsible for the mechanical strength. According to Somna et al. [21], an excess of $\mathrm{OH}^{-}$ions in the system causes the precipitation of aluminosilicates at early stages that promote the decrease of the polymer chains formed. This precipitation is responsible for the decrease in the mechanical strength with increasing curing time, corresponding to a strength loss of about 19\%, as shown in Figure 7 [17], [21].

The higher compressive strength of samples produced with FA-A can be related to two main factors:

I. To the higher dissolution rate of FA-A particles in comparison to FA-B, as can be verified by the presence of residual original fly ash particles on the surface of the specimens GP-B, while no unreacted FA-A particles were observed in the GP-A hardened specimens, see Figure 4. From this image, it is possible to observe a homogeneous surface produced by fly ash A (GP-A), which may also be associated with a higher compressive strength due to higher formation of the N-A-S-H gel when more silicon and aluminum-rich species are released to the system due to a higher amount of FA dissolution [22].

II. Another important factor is the $\mathrm{SiO}_{2} / \mathrm{Al}_{2} \mathrm{O}_{3}$ ratio of the original fly ash, close to 3.52 and 3.34, for FA-A and FA-B, respectively, see Table 2. This modification in the molar ratio of $\mathrm{SiO}_{2} / \mathrm{Al}_{2} \mathrm{O}_{3}$ may be responsible for the inferior mechanical strength observed in the samples prepared with FA-B [24]. This decrease observed in the alkali-activated products can be associated to lower silicon amount in the FA-B compared to the FA-A. The presence of more richsilicon species during the dissolution can be responsible to form the complex structures and cyclic trimmers and species with a large ring with high $\mathrm{SiO}_{2} / \mathrm{Al}_{2} \mathrm{O}_{3}(\mathrm{Si} / \mathrm{Al})$ molar ration in the hardened specimens.

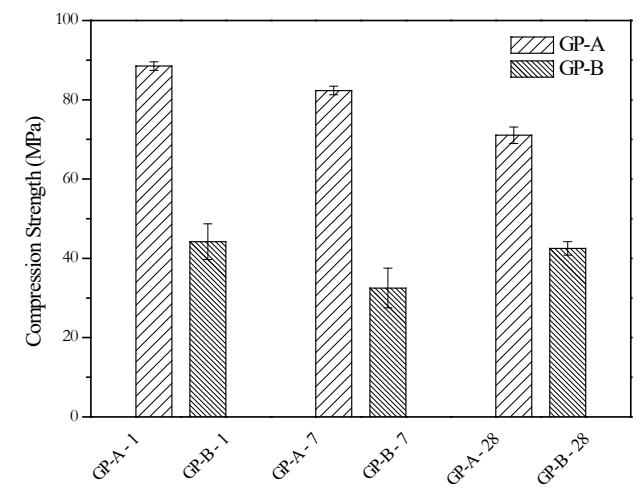

Figure 7. Compressive strength of the alkali-activated materials produced with different fly-ash samples after 1, 7 and 28 days.

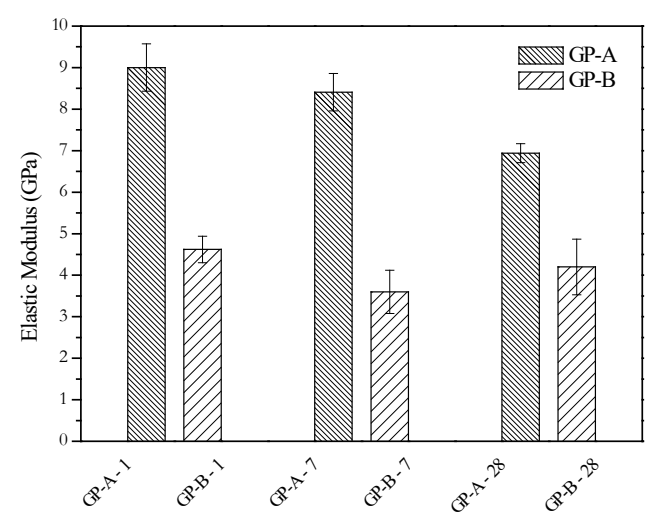

Figure 8. Elastic modulus of the alkali-activated materials produced with different fly-ash samples after 1, 7 and 28 days. 


\section{CONCLUSIONS}

From the results obtained, it can be concluded that both fly ash samples can be used as precursor material in obtaining high mechanical strength alkali-activated materials. The different ashes used as raw material presented different chemical composition, different elemental compositions, different particle size distributions of the spherical particles, and similar surface areas. It was possible to obtain matrices with compressive strength close to $88 \mathrm{MPa}$ after 24 hours of cure at room temperature. The increase in the curing time of the hardened matrices up to 28 days promoted a reduction of the mechanical strength of the GP-A matrices, which was associated with the excess of alkali present in the system after the hardening of the pastes. This alkali excess was observed by carbonation reaction products formed on the surface of samples and observed by the absorption bands in the IRFT. It was observed that the different fly ash samples resulted in materials with different mechanical strength, which has been associated with the dissolution process of the fly ash particles and the subsequent formation of the N-A-S-H gel. It was observed that the increase of $\mathrm{Si} / \mathrm{Al}$ molar ration of the hardened specimens promoted the formation of the high mechanical strength due to the formation of a geopolymeric framework.

The matrices exhibited decreasing water absorption, porosity, and increasing density with increasing of the curing time. The morphology of the inorganic materials after different curing times showed a densified matrix with the presence of some fly ash particles embedded in the aluminosilicate gel. The GP-A matrices showed smaller amounts of unreacted particles, which was related to an increase in the dissolution of the particles, and a larger amount of N-A-S-H gel formed. On the other hand, the matrices produced using FA-A showed an increase in the amount of alkali on the surface after 28 days of curing, which caused a decrease in the compressive strength close to $19 \%$. These results demonstrate that the modification of the ash produced during the production of energy in thermoelectric plants provides different characteristics in the alkali active materials produced. These variations of composition, particle size distribution, and particle morphology must be considered in the fabrication of alkali-activated binders. Alkali activation technology represents an option to replace ordinary Portland cement in some sectors of the construction industry.

\section{ACKNOWLEDGEMENTS}

The authors are grateful for the financial support from the Coordenação de Aperfeiçoamento de Pessoal de Nível Superior (CAPES).

\section{CITATIONS}

[1] A. Ali, T. Job, and P. B. Nidhin, "Geopolymer as repair material," Int. J. Innov. Res. Adv. Eng., vol. 3, no. 9, pp. $2349-2763,2016$.

[2] Sindicato Nacional da Indústria do Cimento, Relatório Anual, Rio de Janeiro: SNIC, 2013.

[3] F. L. Pedroso, "Concreto e construções," IBRACON Brasil, vol. 52, pp. 37-46, 2008.

[4] R. Davidovits and C. James, "Proceedings of the World Congress Geopolymer," in Géopolymère '99, 2nd Intern. Conf., France, Saint-Quentin, France, 1999.

[5] J. L. Provis and J. S. J. van Deventer, Geopolymers: Structures, Processing, Properties and Industrial Applications, USA: Woodhead Publishing, 2009. https://doi.org/10.1533/9781845696382.

[6] J. L. Provis and S. A. Bernal, "Geopolymers and related alkali-activated materials," Annu. Rev. Mater. Res., vol. 44, pp. 299-327, 2014, http://dx.doi.org/10.1146/annurev-matsci-070813-113515.

[7] J. Davidovits and D. Comrie, "Long term durability of hazardous toxic and nuclear waste disposals," in Proc. 1st European Conf. Soft Miner, Compiegne, France, 1988, pp. 125-134.

[8] J. Davidovits, "Geopolymer '88," in Proc. 1st European Conf. Soft Miner., Compiegne, France, 1988, pp. 25-48.

[9] A. G. S. Azevedo and K. Strecker, "Influência da Composição Química das Soluções Alcalinas Ativadoras na Produção de Geopolímeros a Base de Cinza Volante," Rev. Eletr. Mater. Process, vol. 12, pp. 39-46, 2017.

[10] M. Soutsos, A. P. Boyle, R. Vinai, A. Hadjierakleous, and S. J. Barnett, "Factors influencing the compressive strength of fly ash based geopolymers," Constr. Build. Mater., vol. 110, pp. 355-368, 2016, http://dx.doi.org/10.1016/j.conbuildmat.2015.11.045.

[11] W. K. Part, M. Ramli, and C. B. Cheah, "An overview on the influence of various factors on the properties of geopolymer concrete derived from industrial by-products," Constr. Build. Mater., vol. 77, pp. 370-395, 2015, http://dx.doi.org/10.1016/j.conbuildmat.2014.12.065.

[12] A. Fernández-Jiménez and A. Palomo, "Composition and microstructure of alkali activated fly ash binder: Effect of the activator," Cement Concr. Res., vol. 35, pp. 1984-1992, 2005, http://dx.doi.org/10.1016/j.cemconres.2005.03.003. 
[13] M. Zhang, T. El-Korchi, G. Zhang, J. Liang, and M. Tao, "Synthesis factors affecting mechanical properties, microstructure, and chemical composition of red mud-fly ash based geopolymers," Fuel, vol. 134, pp. 315-325, 2014, http://dx.doi.org/10.1016/j.fuel.2014.05.058.

[14] S. Andini, R. Cioffi, F. Colangelo, T. Grieco, F. Montagnaro, and L. Santoro, "Coal fly ash as raw material for the manufacture of geopolymer-based products," Waste Manag., vol. 28, pp. 416-423, 2008, http://dx.doi.org/10.1016/j.wasman.2007.02.001.

[15] J.G.S. van Jaarsveld, J.S.J. van Deventer, and G.C. Lukey, "The characterization of source materials in fly ash-based geopolymers," Mater. Lett., vol. 57, no. 7, pp. 1272-1280, 2003, https://doi.org/10.1016/S0167-577X(02)00971-0.

[16] S. S. Jahromy et al., "Comparing fly ash samples from different types of incinerators for their potential as storage materials for thermochemical energy and $\mathrm{CO}_{2}$," Materials (Basel), vol. 12, pp. 3358, 2019., http://dx.doi.org/10.3390/ma12203358.

[17] A. G. S. Azevedo, K. Strecker, A. G. Araújo Jr., and C. A. Silva, "Produção de geopolímeros à base de cinza volante usando soluções ativadoras com diferentes composições de $\mathrm{Na}_{2} \mathrm{O}$ e Na $\mathrm{SiO}_{3}$," Ceramica, vol. 63, pp. 143-151, 2017, http://dx.doi.org/10.1590/036669132017633662078.

[18]International Organization for Standardization, Ceramic Tiles - Part 3 - Determination of Water Absorption, Apparent Porosity, Apparent Relative Density and Bulk Density, EN ISO 10545-3:1998, 1998.

[19] Associação Brasileira de Normas Técnicas, Concreto - Ensaio de Compressão de Corpos-de-prova cilíndricos, ABNT NBR5739:2007, 2007.

[20]ASTM International, Standard Specification for Coal Fly Ash and Raw or Calcined Natural Pozzolan for Use as a Mineral Admixture in Concrete, ASTM-C 618:2001, 2001.

[21] K. Somna, C. Jaturapitakkul, P. Kajitvichyanukul, and P. Chindaprasirt, "NaOH-activated ground fly ash geopolymer cured at ambient temperature," Fuel, vol. 90, pp. 2118-2124, 2011, http://dx.doi.org/10.1016/j.fuel.2011.01.018.

[22] A. G. S. Azevedo and K. Strecker, "Brazilian fly ash based inorganic polymers production using different alkali activator solutions," Ceram. Int., vol. 43, pp. 9012-9018, 2017, http://dx.doi.org/10.1016/j.ceramint.2017.04.044.

[23] P. Duxson et al., "Geopolymer technology: the current state of the art," J. Mater. Sci., vol. 42, pp. 2917-2933, 2007, http://dx.doi.org/10.1007/s10853-006-0637.

[24] G. Kovalchuk, A. Fernández-Jiménez, and A. Palomo, "Alkali-activated fly ash: Effect of thermal curing conditions on mechanical and microstructural development-Part II," Fuel, vol. 86, pp. 315-322, 2007, http://dx.doi.org/10.1016/j.fuel.2006.07.010.

[25] M. S. Morsy, S. H. Alsayed, Y. Al-Salloum, and T. Almusallam, "Effect of sodium silicate to sodium hydroxide ratios on strength and microstructure of fly ash geopolymer binder," Arab. J. Sci. Eng., vol. 39, pp. 4333-4339, 2014, http://dx.doi.org/10.1007/s13369014-1093-8.

[26] A. G. S. Azevedo, K. Strecker, L. A. Barros, L. F. Tonholo, and C. T. Lombardi, "Effect of curing temperature, activator solution composition and particle size in Brazilian fly-ash based geopolymer production," Mater. Res., vol. 22, pp. 1-12, 2019, http://dx.doi.org/10.1590/1980-5373-MR-2018-0842.

[27] A. Palomo, M. W. Grutzeck, and M. T. Blanco, "Alkali-activated fly ashes - A cement for the future," Cement Concr. Res., vol. 29, pp. 1323-1329, 1999.

[28] A. Fernández-Jiménez and A. Palomo, "Mid-infrared spectroscopic studies of alkali-activated fly ash structure," Microporous Mesoporous Mater., vol. 86, pp. 207-214, 2005, http://dx.doi.org/10.1016/j.micromeso.2005.05.057.

[29] J. Temuujin et al., "Utilization of radioactive high-calcium Mongolian fly ash for the preparation of alkali-activated geopolymers for safe use as construction materials," Ceram. Int., vol. 40, pp. 16475-16483, 2014, http://dx.doi.org/10.1016/j.ceramint.2014.07.157.

[30] W. Mozgawa and J. Deja, "Spectroscopic studies of alkaline activated slag geopolymers," Mol. Struct, vol. 924-926, pp. 434-441, 2009, http://dx.doi.org/10.1016/j.molstruc.2008.12.026.

[31] S. F. A. Shah, B. Chen, S. Y. Oderji, M. A. Haque, and M. R. Ahmad, "Improvement of early strength of fly ash-slag based one-part alkali activated mortar," Constr. Build. Mater., vol. 246, pp. 118533, 2020, http://dx.doi.org/10.1016/j.conbuildmat.2020.118533.

Author contributions: AGSA, LFTD and KS: conceptualization, formal analysis, methodology, writing; AGSA and LFTD: data curation.

Editors: Edna Possan, Guilherme Aris Parsekian. 